\title{
脳内血腫除去術における定位的脳手術用内視鏡 システムの開発と臨床応用
}

\author{
蛯名 国彦，金 奉均，鈴木 重晴，岩㴊 隆
}

\section{Development and Clinical Usefulness of Stereotactic Endoneurosurgical System for Intracerebral Hematoma}

Kunihiko Ebina, M.D., Bongyun KIM, M.D., Shigeharu Suzuki, M.D., and

Takashi IwabuchI, M.D.

Department of Neurosurgery, Hirosaki University School of Medicine,

Hirosaki, Japan

Summary : Since computed tomography (CT)-guided stereotactic surgery is essentially blind surgery, it always involves the risk of injuring viable brain tissue and vessels. Thus, we have developed a new endoneurosurgical system for stereotactic brain surgery. This system consists of a neuroendoscope made of a Selfoc ${ }^{\circledR}$ long rod-shaped deflective distribution lens $1.0 \mathrm{~mm}$ in diameter, a special ultrasonic aspirator for fragmentation and aspiration of hard blood clots, a micromanipulator and a specially designed stereotactic attachment device, so that they can be accurately inserted into the optimum position from any direction.

We have applied this stereotactic endoneurosurgical system to 30 cases of intracerebral hematoma comprising 12 putaminal, 11 thalamic, 4 subcortical, 2 brain stem, 1 cerebellar hemorrhage. The mean age was 65 years old, $79 \%$ of patients were over 60 years old, mean hematoma volume was 22 $\mathrm{m} l$, mean rate of removal was $85 \%$, and there was no intraoperative or postoperative hemorrhage. During removal of an intracerebral hematoma, intraoperative bleeding was prevented by the direct observation of microvessels in the wall of the hematoma cavity.

This system was developed to allow application of stereotactic techniques to endoscopic surgery. The stereotactic endoneurosurgery is considered to be less invasive, safer, and more accurate, as it can be applied to removal of intracerebral hematoma.

\section{はじめに}

近年, 定位的脳内血腫除去術は CT, MRI などの画像 診断の進歩や各種の装置の改良と相まって, 多くの施設に 扣いて施行されている113)6)10)14)15). しかしながら, 本手 術方法は，なお，本質的にはblind surgeryであることか
Key words :

- stereotactic operation

- endoneurosurgical system

- Selfoc ${ }^{\circledR}$ lens

- cerebral hematoma

- ultrasonic aspirator

弘前大学医学部 脳神経外科 (受稿日 1994.9.6)〔連絡先： $\overline{0} 036$ 弘前市在府町 5 弘前大学医学部 脳神経外科 蛯名国彦]〔Mailing address: Kunihiko EBInA, M.D., Department of Neurosurgery, Hirosaki University School of Medicine, 5 Zaifu-cho, Hirosaki 036 , Japan] 


\section{定位的手術用内視鏡システムの開発}

\section{1. 定位的脳手術用内視鏡の開発}

今回開発を進めている内視鏡は, 直径 $1 \mathrm{~mm} の 1$ 本の長 い円柱状の Selfoc ${ }^{\circledR}$ lens で構成されて扔り ${ }^{2) 18)}$, 従来のよ うな lensを重ね合わせることによる，空気接触面での反 射損失がないことから，明るく解像力に優れた scope が可 能となった．視野角も $70^{\circ}$ と広い視野を確保している (Fig. 1A-1, 2)。観察範囲を広げるため, 直視型と弱斜視 型の 2 種類を用意，目的に応じて選択できる.

挿入用 probe 外筒 $(F i g .1 A-3)$ を光学視管外套と共用す ることにより，指入用外筒外径 $4.5 \mathrm{~mm}$ に抑えながら，千 ヤンネル径は $2.1 \mathrm{~mm}$ を確保できた。

硬い凝血塊や腫腸などを破砕吸引するための超音波吸引 probe (Fig. 1A-5) や止血操作を可能にする laser probe や 各種の鉗子 (Fig. 1A-4，6，7）などを自在に用いうることが でき，本格的な内視鏡脳手術を可能にしている.

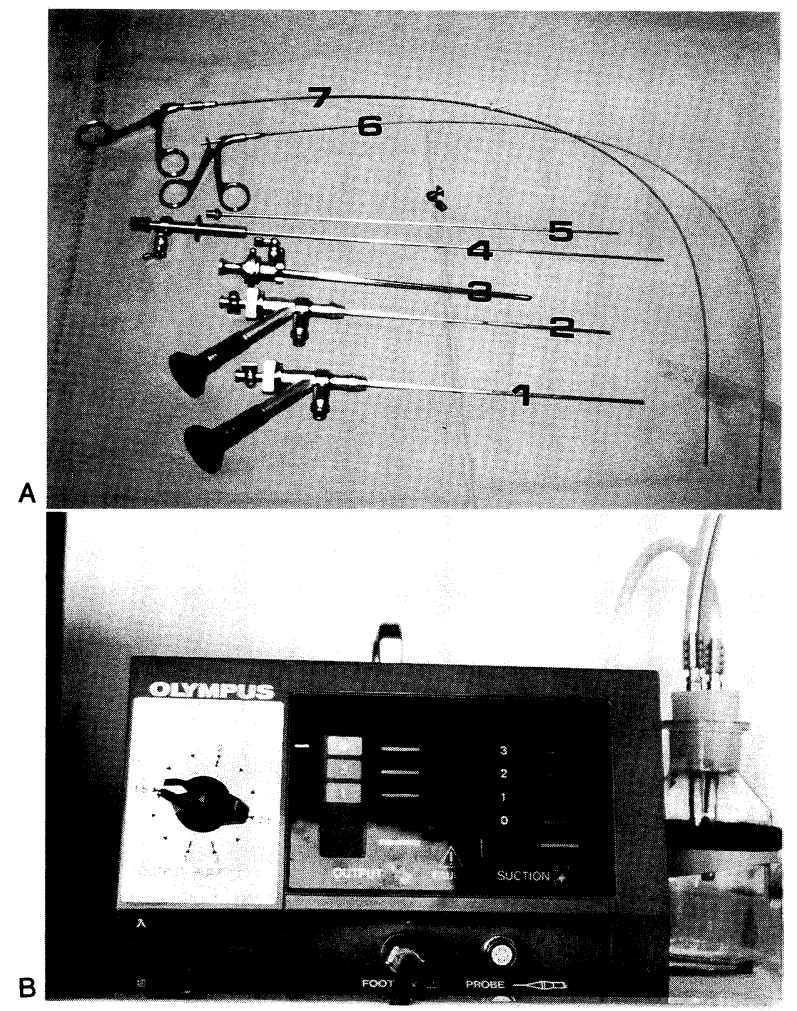

Fig. 1 A: Endoneurosurgical apparatus. 1: neuroendoscope (straight type), 2: neuroendoscope (oblique type), 3: outer probe for endoscope with irrigation cock (4.5 $\mathrm{mm}$ in outer diameter), 4, 6, 7: biopsy probes, 5: oscillating probe $(2.0 \times 1.2 \times 310 \mathrm{~mm})$. B: Improved ultrasonic aspirator system.

\section{2. 超音波吸引装置の改良}

その後, 本システム専用の超音波吸引装置の改良も進め てきたが, probe 先端で最も効率的な縦振動が得られるよ う, probe 外径 $(2.0 \mathrm{~mm})$, 内径 $(1.2 \mathrm{~mm})$, 有効長 $(310$ $\mathrm{mm}$ ) を決定した，共振周波数 $23 \mathrm{kHz}$, 最大出力 $35 \mathrm{w}, 12$ 段階に微調整が可能で, 最大振幅 $90 \mu \mathrm{m}$ と, 原型に比し, 倍近い性能向上を達成している(Fig. 1B).

\section{3．装着固定装置の改良}

定位手術装置に内視鏡超音波吸引装置などを確実に装着 固定し，正確かつ自在に操作しうる micromanipulator を 試作した(Fig. 2A-6)。 また, 装着固定装置も把持固定部 位を歯車構造にして, slip out のない, より安全な構造に 改良した (Fig. 2A-5)。内視鏡 (Fig. 2A-3), 超音波吸引装 置 (Fig. 2A-1) に加之, 光源 (Fig. 2A-4) と超小型軽量 (25 g) video-camera (Fig. 2A-2)を set したところである (Fig. 2A).

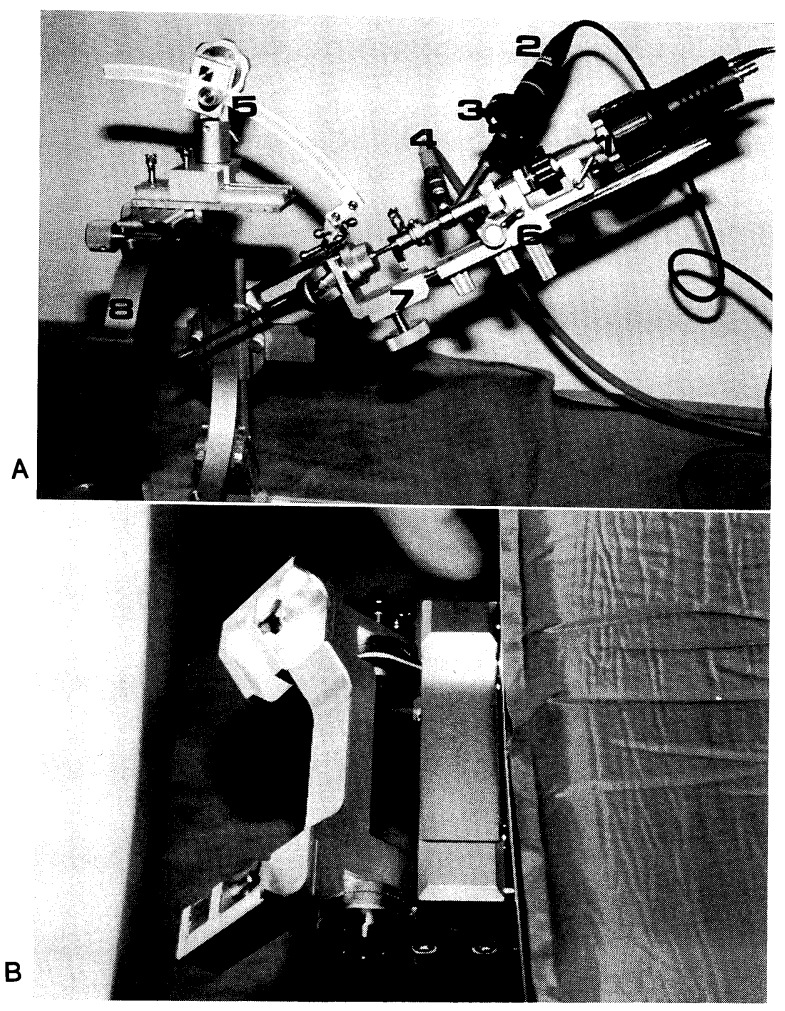

Fig. 2 A: Stereotactic endoneurosurgical system. 1: ultrasonic aspirator, 2: miniaturized video camera 3: neuroendoscope $\left(\right.$ Selfoc $^{\circledR}$ rod lens $1.0 \mathrm{~mm}$ in diameter), 4: light guide, 5: attachment system, 6: micromanipulator, 7: probe holder, 8: Komai's stereotactic frame. B: Flexible CT-table fixation device. 


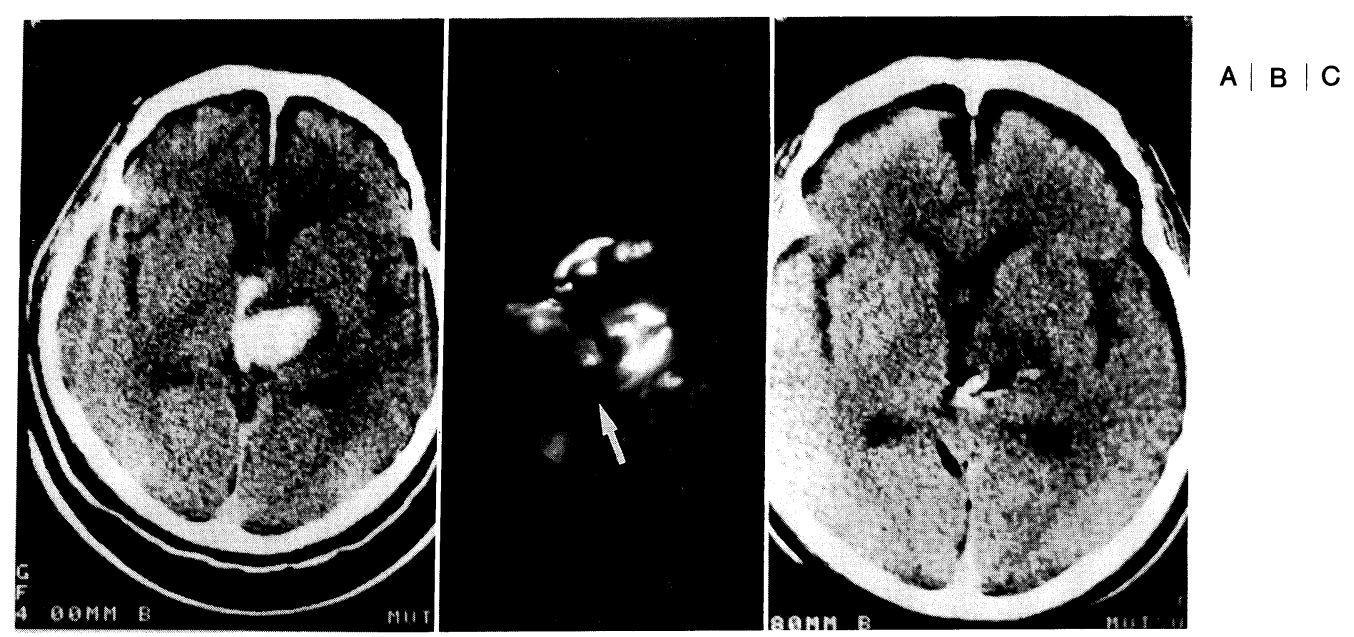

Fig. 3 Case 1. A: Preoperative CT scan showing a left thalamic hematoma spread to the midbrain. B: Intraoperative endoscopic photograph. With use of the ultrasonic aspirator (arrow), a hard blood clot was aspirated strongly. C: Postoperative CT scan showing disappearance of most of the clot.

\section{4. 可変式 CT 台固定装置の開発}

脳内出血症例などにおいては，意識障害などにて舌根沈 下をきたし，気道確保が必要になることもしばしば経験す るところであるが，これらの状態に対処するために，可変 式 CT 台固定装置を試作した。楽な体位で target 決定の ための CT 検査ができるばかりでなく，座標の基準線のず れも抑えられることから，ガントリーの角度を調整するだ けで，その後の座標点の計測がスムーズにできる(Fig. 2B).

\section{CT 自動座標点計測ソフトの利用}

(東芝 Xspeed：ステレオタクテス)の利用

target 設定時には CT コンピューター内蔵ソフト：ステ レオタクテスを使用することにより，座標軸，座標点を瞬 時のうちに計測することができる(Fig. 5A).

\section{臨床応用}

現在までに，本システムを用い脳内血腫吸引除去術を 30 例に施行したが, 男性 18 例，女性 12 例，年齢は 30 81 歳, 平均年齢 65 歳, 60 歳以上が $79 \%$ と開頭術に比し, やや高齢の傾向にある ${ }^{9) 12)}$. 発生部位別では, 被款出血 12 例, 視床出血 11 例, 皮質下 4 例, 脳幹部 2 例, 小脳出 血 1 例で開頭手術に比し視床脳幹部出血の割合が多い ${ }^{912)}$ 平均血腫量は $22 \mathrm{ml}$, 摘出率 $85 \%$ で, 全摘出例は 30 例中 10 例であった。術中・術後出血は認められなかった。発 症から手術日までの期間は 1 17 日, 平均 4.7 日であった

\section{症例 呈 示}

次に本システムを用いての興味ある症例を呈示する.

<症例 1 > 急性期脳幹部出血への応用と強力な吸引装置 の効用.

症例は 70 歳, 男性. 左視床部から, 中脳にかけて直径 $25 \mathrm{~mm}$ ほどの血腫が認められた(Fig. 3A)。JCS 100, 筋 力 $1 / 5$ と血腫 size に比してかなり不良なことから発症 2 日目に本システムを用いて血腫除去術を試みた。

target を血腫深部に設定し, 内視鏡下に血腫の吸引除去 を進めた。

血腫は急性期のため，まだかなり硬く，通常の用手的吸 引では，ほとんど排出しえなかったが，我々の超音波吸引 装置を用いると, 極めて効率よく, 強力に吸引排出するこ とができた(Fig. 3B).

内視鏡にて直視下に, 血腫吸引状況を観察しながら吸引 probe を少しずつ抜いてきたり，また洗浄水の注入を調節 し，血腫を吸引 probe の先まで押し出すことにより，血 腫をきれいに排出することができ，その後の出血の有無も 確認できた，本例の場合，皮膚切開開始から，皮膚縫合終 了まで(skin to skin) 30 分前後で終了した.

術後の CT では, ほぼ血腫が全摘され, 減圧されている のが認められた (Fig. 3C).

術後の経過も良好で, 手術 2 か月後, 意識清明, 杖歩行 にて退院している. 
＜症例 2＞ 内視鏡による血腫腔内小血管の視認と術中 出血の回避.

症例は 44 歳, 男性. 最大径 $55 \mathrm{~mm}(55 \times 30 \times 40 \mathrm{~mm})$ の右被款出血例であるが(Fig. 4A), この症例の場合, 血 腫吸引を続けていると, 突然壁在小血管が専用超音波吸引 probeに吸い込まれてきた，幸いこの超音波吸引 probe は probeの肉厚や長さ, 出力と probe の縦振動振幅の調整な どにより，このような小血管でも温存できるように開発し たが，このまま吸引を続けていたら，術中出血をきたした 可能性がある (Fig. 4B).

本症例の場合, 急いで吸引チューブそのものをはずして 血管からの離脱をはかることができ，ことなきを得た。こ のようなことが可能なのも内視鏡下に観察し, 緊急事態を すばやく把握できたからであり，この内視鏡システムの有 用性をもっとも発揮できた場面といえる。

\section{〈症例 3> 大きな血腫でも one burr hole のもと内視鏡 下手術で全摘可能.}

症例は 81 歳, 女性. 左被款部出血例で, 血腫は前後径 $80 \mathrm{~mm}$, 横径 $30 \mathrm{~mm}$ ほどである (Fig. 5B). 通常の定位手 術においては, 吸引操作そのものが blind であることから 安全性と血腫吸引効率などを考慮して, target を血腫の中 央部に設定することが多いと思うが，本システムにて， real time で吸引状況を把握しながら種々操作ができるこ とから,このように, 大きな血腫でも, 血腫深部に target を設定し(Fig. 5A), 血腫の長軸方向から approach して, probe を引き抜きながら効率よく血腫を除去することによ り, 全摘可能になる (Fig. 5C).

\section{＜症例 4> 後頭葉内皮質下血腫全摘により全盲状態から 劇的に視力・視野の回復.}

症例は, 69 歳, 女性. 全盲状態から視野の改善の得ら れた症例である。

3 年前 (H 2.1.24), 左同名性半盲で発症し, CT では, 右の頭頂後頭葉に大きな血腫がみられたが $(56 \times 40 \times 24$ $\mathrm{mm})$ ，保存的に治療していた(Fig. 6A).

10か月後の視野表では，左同名性四半盲が残存していた． それから 2 年後 (H 4.7.3.15:00), 外出から帰って, まもなく両眼視力, 視野の低下に気づき, 3 時間後には両 眼とも光覚程度まで低下し，当科を受診した $(18 ： 00)$.

対光反射は両眼直接間接とも prompt で，いわゆる皮質 盲 (cortical blindness) の型と思われる. 血圧は211/116 $\mathrm{mmHg}$ と上昇していた.

CT にては, 対側の左頭頂後頭葉皮質下に直径 $30 \mathrm{~mm}$ $(30 \times 20 \times 20 \mathrm{~mm})$ ほどの出血がみられる $($ Fig. 6B).

一般に脳卒中による皮質盲の場合, 視力・視野の予後は

112 脳卒中の外科 $23: 1995$

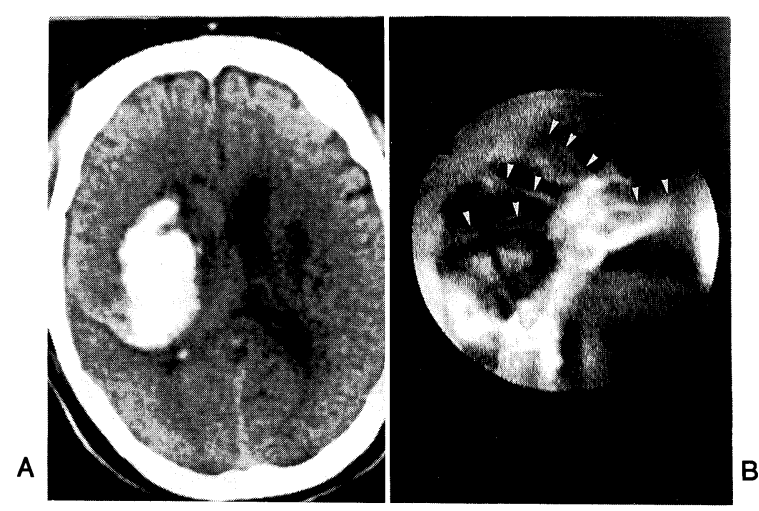

Fig. 4 Case 2. A: Preoperative CT scan revealed a large hematoma in the right putaminal region. B: Intraoperative endoscopic photograph. Small blood vessels (arrowheads) in the wall of the hematoma cavity are clearly demonstrated.

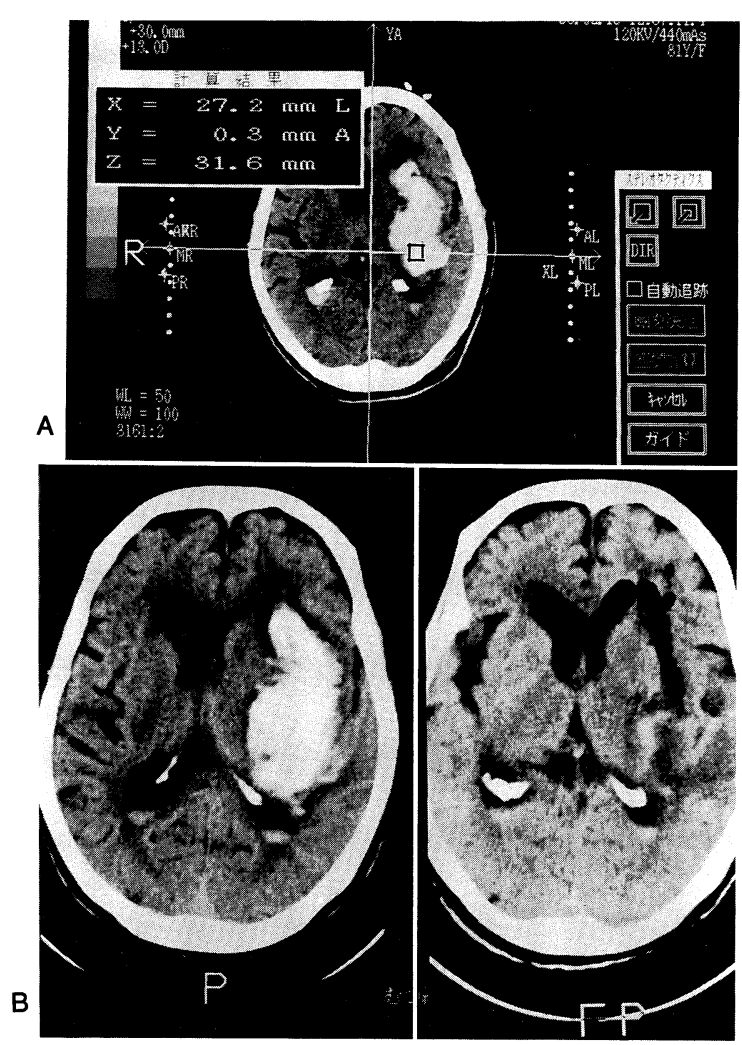

Fig. 5 Case 3. A: Intraoperative CT scanning calculation of the coordinates of the evacuation target poing by stereotactes. The target was set on the deep side, and the approach was made from the direction of the long axis of the hematoma. B: Preoperative CT scan showing a left massive putaminal hematoma. C: Postoperative CT image revealed aspiration of most of the hematoma. 


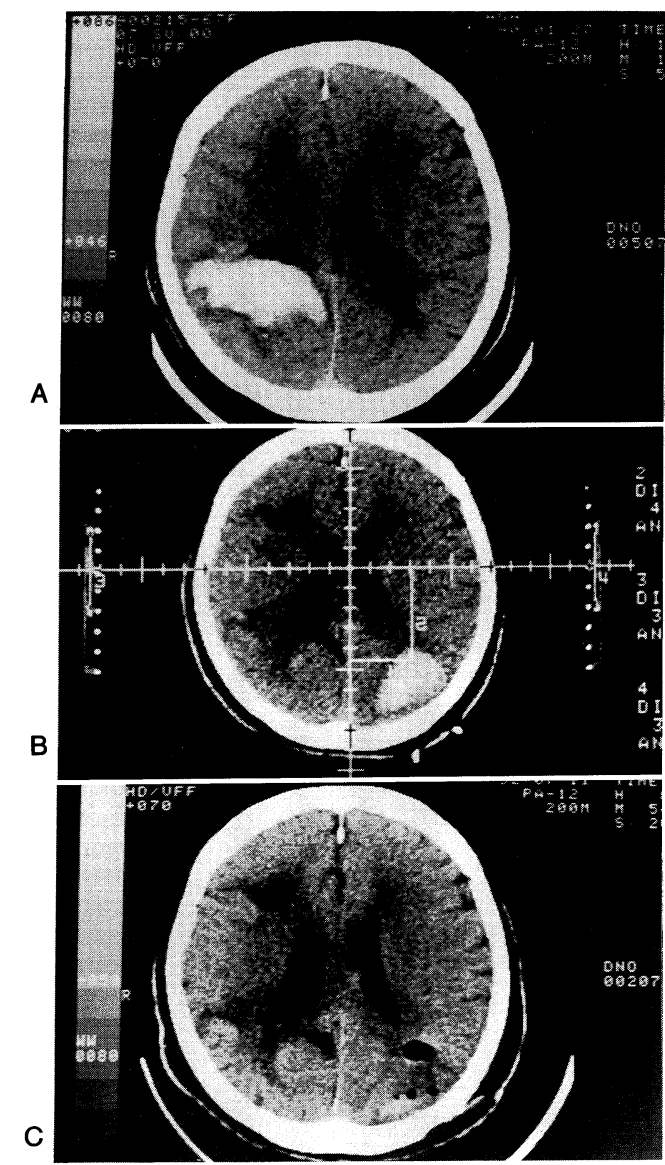

Fig. 6 Case 4. A: The CT image of the initial stroke showing a hematoma in the right parietooccipital subcortical region. B: Preoperative CT scan of the second stroke showing a hematoma in the left parieto-occipital subcortical region. C: Postoperative CT scan revealed removal of the hematoma totally.
不良といわれているが，本例の場合も，その後視力・視野 の改善の得られないことから，本システムを用いて approach することとし，7月10日 target を血腫深部に設 定し，左後頭葉に one burr hole を扔いて内視鏡下に血腫 腔内を観察しながら, 専用超音波吸引装置にて吸引を進め ていった.

術後の CT では左頭頂後頭葉の血腫が全摘されている (Fig. 6C).

な㧍, 血腫壁内の小血管の biopsy 所見では, amyloid angiopathy は証明されなかった。

術直後より, 再び光を取り戻し, 視力・視野の改善傾向 が認められ, 手術 2 か月後には, 再出血前近くまで, 著明 な視野の改善を得た(左同名性半盲十右上四半盲) (Fig. 7). 本例は本内視鏡システム手術の最も劇的な効果の得られ た症例の一つであった。

\section{考察}

1970 年代後半に始まった定位的脳内血腫除去術は，そ の簡便性と低侵襲性を認如妃34)14)15), また術後脳血流 量の改善 ${ }^{19)}$ や機能回復 ${ }^{13)}$ の面などからも評価されてきて いる. 症例 1 のような視床・脳幹部出血 ${ }^{112) 16) 19)}$ では, そ の $20 \%$ 近くが吸引療法の適応となって㧍り, また高齢者, 合併症を伴う患者 ${ }^{6)}$ などに対しても広く諸施設において施 行されている(10)12). しかし，いずれにしても本質的には blind surgeryであることから，開頭手術に比して，その 血腫除去効率や術後出血などの点でな拉議論のあるところ である，岩渕の集計報告 ${ }^{9)}$ では術後出血率は開頭手術法 $3.0 \%$ に比し, 吸引療法は $7.8 \%$ であり, 倍以上の高率で あった。また，血腫除去率も吸引療法は，通常 50～70\% で開頭手術法に比し，かなり低い傾向にある ${ }^{912)}$.

血腫吸引状況を直視下に観察しながら吸引しうるなら， 的確な吸引操作が可能となり, 血腫除去率の向上と術中・

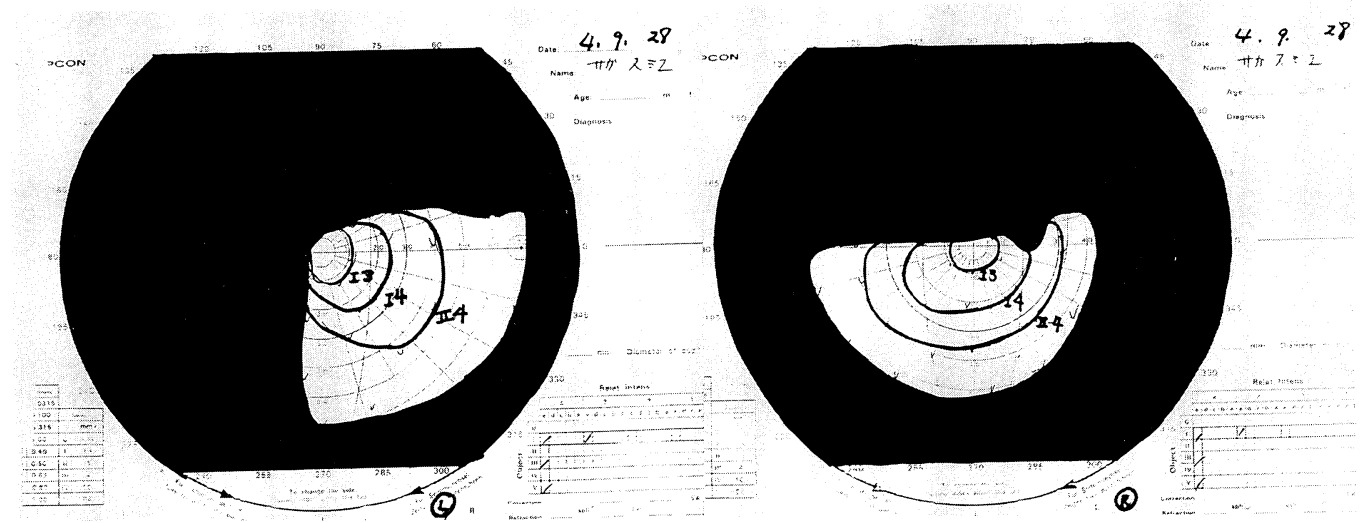

Fig. 7 Visual field after endoneurosurgical evacuation revealed dramatic improvement from cortical blindness. 
術後出血の低減に大いなる効果があると信じ，内視鏡シス テムの開発・改良を進めてきた2).

本システムは Selfoc ${ }^{\circledR}$ lens 応用の内視鏡と硬い凝血塊吸 引のための専用超音波吸引装置, 定位手術手技応用のため これらを装着固定するための装着装置の 3 つの主要機器か ら構成されている。

Selfoc ${ }^{\circledR}$ lens $は^{18)}$ ，日本板硝子 (大阪) が 1968 年，世界 に先駆けて実用化に成功したレンズであり，一般には，屈 折率分布型レンズ, または不均等媒質レンズとも呼ばれて いる. すなわち, 化学的イオン交換法などにより, レンズ 内部の屈折率が中心から外周に向かって低くなっているた めに, レンズ内に入射した光線は, レンズ内部で屈折を繰 り返しながら，ほとんど減衰することなく先端部に進み， 正位等倍実像を結像することができる.

このような特質から 1 本の長いロッド状レンズが可能と なり，通常のリレーレンズのようにレンズを重ね合わせる ことによる空気接触面での反射損失や，レンズとレンズの 間 (空気間隙)での損失がないことから, 細いにもかかわら ず極めて明るく, 解像力に優れた内視鏡をつくることがで きた. 基底核部・視床部近傍の穿通枝や直径数ミクロンの 血管も識別可能である. また明るさ, 解像力とも幅方向で 一様である. 更に, 超近接の $1 \mathrm{~mm}$ から無限遠まで明視で きる深い観察深度と, 広視野角をもつため狭い脳内でも正 確な部位のオリエンテーションがつけやすく, 手術操作が 飛躍的に安全かつ確実なものとなった. 観察範囲を広げる ため弱斜視型 (視野角 $60^{\circ}$ ) と直視型 (視野角 $70^{\circ}$ )の 2 種類 を用意，使用目的に応じて選択できる.

急性期の硬い凝血塊の吸引除去のためには Archimedean screw の応用 ${ }^{5)}$, SAS \& $\mathrm{A}^{8)}$, 超音波吸引装置の開 発17) や, 血腫腔内ドレナージ留置 ${ }^{4)}$ と urokinase 血腫溶解 洗浄法 ${ }^{3)}$ 7)11) などが試みられ, それなりの効果が報告され てきている.

今回, 我々がこれら急性期の硬い凝血塊の吸引除去のた めに, 本システム専用として改良を進めてきた超音波吸引 装置は, フットスイッチを踏むと, 振動子の圧電素子 (PZT) に本体のジェネレーターから発振周波数 $23 \mathrm{kHz}$ の交流電圧が加えられる. 圧電素子には数 $\mu \mathrm{m}$ の振動が 発生し, これをホーン部で拡大, 発振棒の先端部分で最も 効率的な縦振動が得られるよう, また, 血腫腔内の小血管 の損傷を可及的に少なくするように，動物実験など基礎的 成果をふまえ, 超音波吸引 probe の肉厚や長さ, 出力と probe 縦振動振幅の調整を進め, 発振棒 (probe) の外径, 内径, 有効長を決定した. 出力 $35 \mathrm{w}$ で最大振幅 $90 \mu \mathrm{m}$ になり, $2.0 \times 1.2 \times 310 \mathrm{~mm}$ (外径 $\times$ 内径 $\times$ 有効長 $), 2.0$ $\times 1.3 \times 310 \mathrm{~mm}, 1.8 \times 1.1 \times 295 \mathrm{~mm}$ の 3 種類である.

我々は, 脳内血腫除去術における strategyとして次の
手順が肝要と考えている.

1 ) 内視鏡下に血腫腔内を直視下に観察しながら，2） targetを血腫最深部に設定し，3) 血腫の長軸方向から approach，4)脳組織や血腫腔内の血管を損傷しないよう 血腫吸引状況を確認しながら， 5 ) 徐々に probe を引き抜 きながら，6) 洗浄水 (術中出血予防のため, 生食 $100 \mathrm{ml}$ にトロンビン 10,000 単位を溶解したものを用いている)の 注入を上手に用いて probe 先端にむけて凝血塊を押し出 す. 6 ) 急性期の硬い凝血塊除去には超音波吸引装置を効 果的に用いる. 血腫腔内の小血管を損傷しにくい点でも用 手吸引より優れていると考えている.

また, 超音波吸引装置は, その強力な吸引効果ゆえに, 症例 2 に紹介したように, 内視鏡下で直視下観察しながら 用いないとアッという間に脳組織や血管などを吸引してし まうことがあり, 我々は超音波吸引装置を, より効率的に 用いるためにも内視鏡システムは必須のものと考えている。 血腫の効率的吸引除去のためには, 吸引装置の選択とと もに，血腫深部における targetの設定と可及的長軸方向 からの approachの routeの決定が極めて重要と考えてい る. そのため穿頭部位の決定は特に慎重にならなくてはい けない. 我々は穿頭部位の微調整のため, 座標決定の際, 必ず穿頭予定部位にmarkerを置いてCTを撮影し，その的 確を期している.

こうすることにより, 内視鏡下に血腫吸引状況を把握可 能なことから, 症例 3 のように大きな血腫でも, 2 力所以 上の穿頭 ${ }^{7)}$ による侵襲を加えなくとも除去可能となる.

また, 谷中ら ${ }^{20)}$ は術前穿刺針の通過経路の重要性を強 調し, 穿刺経路の検討可能な coordinate softwareの有効 性を報告している.

定位的脳内血腫除去術は内視鏡システムの応用により, より安全に, より効率的に手術操作を進めることが可能と なることから, 今後ますます，その新たな適応を拡げて行 くことが期待される.

\section{結 語}

脳内血腫除去術に際して, 定位的脳手術用内視鏡システ ムの応用により, 専用超音波吸引装置の開発と相まって, 視床・脳幹部出血や高齢者や合併症の多い患者においても 低侵襲性のもと, より安全, より効率的に，速やかな手術 操作が可能となり, 臨床的にも効用大なるものと思われた

本論文の要旨は第 23 回日本脳卒中の外科研究会 (1994 年 3 月 京都）において発表した。

稿を終えるにあたり, 本システムの開発において, 全面的にご 協力いただきましたオリンパス光学の山口達也氏, 窪田哲丸氏,

114 脳卒中の外科 $23: 1995$ 
唐沢 均氏, 戸山初高氏, 茂野浩樹氏, 森山啓二氏ほか関係諸氏 に深謝申し上げます。

\section{文献}

1) Beatty RM, Zervas NT: Stereotactic aspiration of a brain stem hematoma. Neurosurgery 13: 204-207, 1983

2) Ebina $\mathrm{K}$, Andoh A, Takahashi $\mathrm{T}$, et al: Development and clinical usefulness of a new neuroendoscope system for CTguided stereotactic brain surgery. Neurol Med Chir (Tokyo) 30: 401-407, 1990

3）土井英史, 森脇 宏, 駒井則彦, ほか：高血圧性脳出血に 対する定位的血腫溶解排除法. Neurol Med Chir (Tokyo) 22: 461-467, 1982

4) 林 実, 長谷川健, 古林秀則, ほか：高血圧性脳出血に対 する定位脳手術的血腫除去. 脳神経外科 9: 1365-1371, 1981

5) Higgins AC, Nashold BS: Modification of instrument for stereotactic evacuation of intracerebral hematoma: Technical note. Neurosurgery 7: 604-605, 1980

6) Hokama M, Tanizaki Y, Matsuo K, et al: Indications and limitations for CT-guided stereotaxic surgery of hypertensive intracerebral haemorrhage, based on the analysis of postoperative complications and poor ability of daily living in 158 cases. Acta Neurochir (Wien) 125: 27-33, 1993

7）堀本長治, 山鹿誠一, 鳥羽 保, ほか：巨大な高血圧性脳 出血に対する定位的血腫溶解吸引術. 脳神経外科 21: 509512,1993

8）伊藤治英, 向井裕修, 北村昭洋, ほか：定位脳手術用 Aqua-stream and Aspirator (SAS \& A) を用いた高血圧性 脳内血腫除去術. 脳神経外科 17: 939-943, 1989

9）岩㴊 隆：高血圧性脳出血（1）被款出血. 脳卒中 12: 525540,1990

10）金谷春之：高血圧性脳出血の治療の現況一全国調査の成績
より一. 脳卒中 $12: 509-524,1990$

11) Mohadjer M, Eggert R, May J, et al: CT-guided stereotactic fibrinolysis of spontaneous and hypertensive cerebellar hemorrhage: Long-term results. J Neurosurg 73: 217-222, 1990

12）中井 昴：高血圧性脳出血 ( 2 ) 視床出血. 脳卒中 12: 541555,1990

13）興村義孝, 小野純一, 岩立康男, ほか：軽症被款出血例に 対する CT 誘導定位的血腫吸引術の評価. 脳神経外科 19: 611-617, 1991

14）七條文雄, 松本圭蔵：CT-controlled stereotactic operation による高血圧性脳内血腫除去術. その1 理論と手術術式 について. 脳神経外科 13: 845-852, 1985

15）七条文雄, 松本圭蔵：CT-controlled sterotactic operationに よる高血圧性脳内血腫除去術. その2：視床並びに大脳基底 核部の小血腫除去例．脳神経外科 13: 945-952, 1985

16）高浜秀俊, 森井 研, 佐藤光弥, ほか: 高血圧性橋出血に 対するCT定位血腫除去術一保存的治療との比較検討一. 脳 神経外科 17: 733-739, 1989

17）富田恵輔, 堀江周二, 行天徹矢, ほか：高血圧性脳出血に 対する血腫吸引術の手術成績; とくに急性期基底核部出血例 について. 第 1 回脳出血ワークショップ講演集, にゅーろ ん社, 東京, 1986, pp 63-72

18) Uchida T, Furukawa M, Kitano I, et al: Optical characteristics of a lightfocusing fiber guide and its applications. IEEE J Quantum Electronics 6: 606-612, 1970

19）上田幹也, 森永一生, 松本行弘, ほか：視床出血に対する 定位的血腫吸引術の single photon emission CTによる評価. 脳神経外科 18: 25-31, 1990

20）谷中清之, 江頭泰平, 岡崎匡雄, ほか：Coordinate software の定位的血腫吸引除去術への応用. 脳神経外科 18 : 623-629, 1990 